\title{
Eurokrisen og EU: Fra utilstrækkelige strategier til problematisk føderalisering?
}

Morten Kelstrup

Professor Emeritus, Institut for Statskundskab, Københavns Universitet

Den såkaldte 'eurokrise' omfatter et indviklet kompleks af forskellige økonomiske og politiske kriser. Artiklen identificerer nogle af de vigtigste kriser og søger at karakterisere EU's svar på disse. Den kommer frem til, at EU's nuværende prioritet af en retlig-administrativ budgetkontrolstrategi, der økonomisk indebærer en sparepolitik i en lavkonjunktur, er klart utilstrækkelig, og at EU's aktuelle planer om en føderalisering af eurozonen, der i høj grad ligger i forlængelse heraf, vil skabe nye problemer, såfremt de gennemføres.

\section{EU's vej fra relativ stabilitet til ny krise}

Denne artikel forfølger det synspunkt, at EU og eurosamarbejdet er ramt af mange kriser samtidig, og at en sondring mellem forskellige kriser gør det klarere, hvad man kan løse med hvilke strategier, og dermed også hvilke problemer man fortsat mangler løsninger på. Der sondres i det følgende analytisk mellem 1) de kriser der er knyttet til det generelle globaliseringspres, 2) den finansielle krise, 3) den økonomiske krise i bred forstand, 4) budget- og statsgaldskriserne, 5) 'statsgaldsfalderne', 6) den sarlige graske krise og 7) de politiske kriser, der delvist - men også kun delvist - er følgevirkninger af de økonomiske. En sådan opregning af kriser kan virke overdreven. Når sondringerne laves, er det ikke for at deltage i nogen konkurrence om, hvor mange kriser man kan opregne. Det er heller ikke for at hævde, at disse kriser er uafhængige af hinanden, tværtimod. Men det er for at få struktur og brede perspektiver ind i den vanskelige analyse af eurokrisen og EU's reaktioner på denne.
Den sidste del af artiklen diskuterer EU's strategier. Et hovedsynspunkt er, at EU i meget høj grad - og for høj grad - satser på en retlig-administrativ budgetkontrolstrategi, der ligger i forlængelse af den strategi, der allerede tidligt har ligget i ØMU'ens konvergenskrav og EU's Vækst- og Stabilitetspagt. Den økonomiske konsekvens af denne strategi er, at en række stater midt i en lavkonjunktur tvinges til at føre kraftig besparelsespolitik. De økonomiske, sociale og politiske problemer i de mest ramte EU-lande er imidlertid så alvorlige, at man bliver nødt til at komme frem til andre politikker og virkemidler. EU's aktuelle tanker om eventuelt at tage skridt i retning af en stærkere føderalisering inden for Eurozoneområdet vurderes til at være en strategi, der både er farlig for sammenholdet i EU og utilstrækkelig i forhold til de problemer, man står over for. Debatten om nye traktatændringer og en ny føderation kan næppe undgå at stå i vejen for andre og vigtigere reaktioner på de aktuelle kriser.

I den følgende analyse tages der udgangspunkt i følgende generelle billede af EU's økonomiske, politiske og retlige udvikling: ${ }^{1}$ Det europæiske samarbejde har igennem ca. 60 år udviklet sig til det økonomiske, politiske og retlige system, som EU er i dag. Det er vigtigt, at alle disse tre dimensioner har været med hele vejen. Det oprindelige økonomiske samarbejde var domineret af liberalisering (med basis i de fire 'friheder' og det indre marked). Efterhånden har der dog udviklet sig en forholdsvis stærk retlig reguleringspolitik, således at EU i dag må karakteriseres som både et politisk og retligt system og en art rammeøkonomi der udbygger det indre marked, jf. også at begrebet 'social markedsøkonomi' indgår i Lissabontrak- 
taten (TEU, art. 3). Kriser har været normale i EU, og det er ofte i reaktionerne på kriserne, at EU har udviklet en yderligere integration (Marcussen \& Ronit, red., 2012). Ved Lissabontraktatens ikrafttræden i 2009 var den dominerende forventning, at det nu var slut med større traktatændringer foreløbig. Men man havde ikke taget højde for de økonomiske kriser, der meldte sig fra omkring 2008 som følge af den internationale finanskrise. Disse har nu bredt sig til også at blive politiske kriser, både for de særligt ramte lande i Europa og for hele EU-systemet. Det er dette seneste kompleks af økonomiske og politiske kriser, der er emnet for denne artikel.

Den nuværende situation omkring Eurosamarbejdet må naturligvis ses på baggrund af den historiske udvikling, der har ført frem til etableringen af ØMU'en. Man skal ikke glemme, at valutauro tidligt var et meget stort problem for den økonomiske udvikling i Europa. Med flydende valutakurser var der i 1960'erne og 1970'erne med jævne mellemrum store valutakriser og gentagne og undertiden også mislykkede - forsøg på at stabilisere valutaforholdene. De positive erfaringer med EMS'en (fra 1979 til 1993) var en væsentlig forudsætning for etableringen af ØMU'en. Planen for ØMU'en blev formelt vedtaget med Maastrichttraktaten, der blev forhandlet på plads i 1991 og trådte i kraft i 1993. ØMU'en blev i bemærkelsesværdig grad gennemført i overensstemmelse med planerne, og antallet af medlemmer, der gik over til anvendelsen af euroen, blev udvidet fra 12 til 17 (Kelstrup et al., 2012, 295ff). Frem til omkring 2009, altså omkring tidspunktet for ikrafttrædelsen af Lissabontraktaten, fremstod ØMU'en som en af EU's helt store successer (Nedergaard 2008, Vastrup 2009). Deltagelse i $\varnothing \mathrm{MU}-$ samarbejdet indebar en forpligtelse på ØMU'ens konvergenskrav, bl.a. kravet om at det årlige offentlige underskud ikke må overstige 3 procent af bruttonationalproduktet, og at den offentlige bruttogæld som hovedregel ikke må overstige 60 procent af bruttonationalproduktet. Med indtræden i eurozonen gav de deltagende lande 'endegyldigt' afkald på at have deres egen valuta og på deres egen mulighed for at føre selvstændig pengepolitik (herunder muligheden af at devaluere).

EU har imidlertid været igennem en dramatisk udvikling på det økonomiske område efter, at den finansielle krise ramte Europa i 2008 (Jespersen, 2012, Thygesen, 2012, Jensen, 2011, Kelstrup et al., 2012, især 303-23). Tallene taler deres eget sprog. ${ }^{2}$ Den gennemsnitlige arbejdsløshed i EU var i november 2012 10,7\% og tilsyneladende fortsat stigende. EU's gennemsnitlige vækst var kun 1,5\% i 2011 og tæt på nul i 2012. Den gennemsnitlige offentlige gæld for EU som helhed var i juli 2012 $88,2 \%$ af BNP, mens det gennemsnitlige underskud på statsbudgetterne var 4,5\% i 2011. På begge disse dimen- sioner ligger EU's gennemsnit væsentligt over ØMU'ens konvergenskrav på hhv. $60 \%$ og $3 \%$. Disse og mange andre tal sætter EU's optimistiske målsætninger på det økonomiske område, som de bl.a. kendes fra Lissabonstrategien, i skarpt relief. EU's centrale aktører har i de seneste tre-fire år været tvunget til at koncentrere sig om krisestyring og skadesbegrænsning.

I dag har man både det analytiske spørgsmål: Hvorfor gik det galt? Og det mere fremadvendte spørgsmål: Hvad er perspektiverne? I det følgende gives et kort overblik over nogle af de vigtigste kriser, der indgår i den nuværende eurokrise, og derefter en diskussion af disse spørgsmål. Artiklen foregiver ingenlunde at give udtømmende svar. Den er et forsøg på at bidrage til en bred og differentieret analyse af EU's nutidige situation. Den er samtidig en advarsel mod at dække problemerne til ved en ny føderaliseringsstrategi for eurozonen.

\section{EU's økonomiske kriser ${ }^{3}$ EU og den globale konkurrence}

Lad det være understreget, at vi har at gøre med en analyse af EU's økonomi inden for en meget konkurrencepræget international økonomi. Den internationale konkurrence har taget overordentligt til, særligt efter den liberaliseringen af internationale kapitalbevægelser, der blev gennemført fra slutningen af 1980'erne. Der er - med en voldsom kraft i de seneste år - kommet en øget konkurrence fra de nye industrilande, særligt BRIK-landene. Den skærpede konkurrence påvirker i dag alle stater, uanset om de er medlem af EU eller eurozonen eller ej. ${ }^{4}$ Påstandene knyttet til Europas vanskeligheder med at klare sig i den internationale konkurrence og forudsigelserne om Europas dystre fremtid i den globale økonomi er undertiden meget drastiske. Her kan vi ikke gå i detaljer. Men uanset om man i dag vil tale om en generel 'globaliseringskrise' eller kun vil tale om et 'globaliseringspres', må man - også i en analyse af eurokrisen - fastholde, at der er nye og vanskelige globale rammebetingelser, som øver indflydelse på hver enkelt stats økonomi og handlemuligheder. ${ }^{5}$

\section{EU's finansielle krise og problemerne i banksektoren}

EU blev som bekendt ramt hårdt af den finanskrise, der i 2007-08 brød ud med udspring i den amerikanske boligog finanssektor. Efter at den amerikanske investeringsbank Lehman Brothers gik konkurs i september 2008, kom der også bankkriser i Europa. Virkningen var, at kreditmarkederne tenderede mod at 'fryse til', og den finansielle krise udviklede sig i anden omgang til en egentlig økonomisk krise forstået som en kraftig nedgang i $ø$ konomisk aktivitet og beskæftigelse. For at undgå yderligere bankkrak og de skadelige virkninger, som dette bl.a. ville medføre for beskæftigelsen, var reaktionen i de 
enkelte stater - både inden for og uden for EU - at vedtage forskellige former for bankpakker. Efter 4-5 år er der fortsat mange tegn på, at en række europæiske banker er truede. Det er fortsat en central og delvist uløst opgave at etablere kontrol med den finansielle sektor og sikre en stabilisering af de europæiske banker. Vi skal vende tilbage til, hvorledes dette ligger til grund for EU's planer om at etableret en bankunion for eurozonen.

\section{EU's økonomiske krise i bredere forstand}

Den økonomiske krise i Europa udviklede sig alvorligt efter 2008. Det er karakteristisk og i forståelsen af den nuværende situation meget vigtigt, at udviklingen har været meget forskellig for de enkelte stater. Nogle stater blev særlig alvorlig ramt, således Portugal, Irland, Italien, Grækenland og Spanien. For alle disse lande har der samlet i perioden fra 2007 til 2011 været tale om en negativ økonomisk vækst. Mens der er tale om forbedringer for Irlands vedkommende, er prognoserne for de øvrige PIIGS-lande dystre.

En anden effekt af den økonomiske krise var en kraftigt voksende arbejdsloshed. Også her har der været meget store forskelle mellem EU-landene. Arbejdsløsheden i EU-landene nåede sit hidtil højeste niveau i november 2012, hvor den kom op på 10,7\% (og 11,7\% i eurozonen). Arbejdsløsheden er særlig høj i de øst- og sydeuropæiske lande, højest i Spanien med over 26\% og næsten det samme i Grækenland, mens arbejdsløsheden i Tyskland lå på lidt under $6 \%$. Ungdomsarbejdsløsheden var alle steder højere end den almindelige arbejdsløshed, således (i august 2012) 22,6\% for Europa som helhed med over $53 \%$ for Spanien og Grækenland.

Et yderligere vidnesbyrd om, at den økonomiske krise har ramt EU-landene forskelligt, er opgørelserne over de enkelte landes betalingsbalancer. De ovennævnte fem hårdt ramte lande havde også i perioden siden 2007 store underskud på betalingsbalancernes løbende poster (dog med visse forbedringer i den sidste periode, særligt for Irland), mens Tyskland og enkelte andre lande (herunder Danmark) trods krisen kunne opnå forholdsvis store overskud på betalingsbalancerne. For nogle af landene synes underskuddene på betalingsbalancen nærmest at være strukturelle.

Naturligvis er der mange forhold, der er med til at forklare, hvorfor der har været så store uligheder i udviklingen af de enkelte EU-landes økonomier. Den væsentligste forklaring er utvivlsomt de store forskelle $i$ udviklingen $i$ omkostningsstruktur og effektivitet, der er resultat af, at man i meget forskellig grad har gennemført reformer af arbejdsmarkederne og de offentlige sektorer. I sammenligninger af udviklingen i de relative enhedsomkostninger i de private sektorer er det markant, at Tysklands enhedsomkostninger i det seneste årti er faldet, mens omkostningsniveauet i flertallet af EU-lande, særligt i PIIGS-landene, er vokset betydeligt. Denne forøgelse af Tysklands konkurrencedygtighed har bl.a. baggrund i, at man gennemførte store strukturtilpasninger i 1990'erne og begyndelsen af 00 'erne. ${ }^{6}$

\section{EU-medlemsstaternes budget-og statsgeldskriser}

En særlig virkning af både den finansielle og den økonomiske krise har været, at der er opstået ekstraordinært store problemer med de enkelte staters budgetter. I forvejen har de fleste EU-stater haft problemer med at undgå budgetunderskud, også under gode konjunkturer. Det er således sigende, at Italien ikke har haft overskud på de offentlige finanser siden 1970, Frankrig ikke siden 1978 og Portugal ikke siden 1977. Det står lidt bedre til for Tyskland og de nordiske lande (Barsøe, 2011). Den økonomiske krise i de seneste år har skærpet budgetproblemerne. Umiddelbart betyder faldende økonomisk aktivitet, at staterne mister indtægter. Desuden opstår der et stigende udgiftsbehov både til overførselsindkomster og - eventuelt - til konjunkturstimulerende programmer. Yderligere vil bankpakker (naturligvis afhængigt af deres udformning) være ekstra belastninger af staternes udgifter. For de fleste EU-stater har kriserne betydet, at det offentlige underskud for alle årene siden 2008 har ligget væsentligt over den grænse på 3 procent, som kræves overholdt i ØMU'ens konvergenskriterier, og som allerede nævnt er det gennemsnitlige tal for EU-landene for 2011 på 4,5\%.

Underskud på en stats budget medfører naturligvis et behov for låneoptagelse. Der har således været en kraftig vækst i EU-landenes statsgæld. Statsgælden for en række EU-stater i 2011 betydeligt over den grænse på 60 procent, der er indeholdt i ØMU's konvergenskriterier og i Stabilitets- og Vækstpagten. Statsgælden målt i procent af BNP nåede i 2011 for Grækenland op på næsten 170\%, mens den for Italien, Irland og Portugal lå over 100\%. Tyskland ligger omkring EU's gennemsnit, mens Spanien (i 2011) lå noget under dette (idet problemerne i Spanien særligt skyldes de private bankers store gæld). Statsgælden er for næsten alle staters vedkommende øget siden begyndelsen af den økonomiske krise i 2008 .

\section{Kriser knyttet til de sarlige statsgaldsfelder}

Man kan tale om en statsgaldskrise, når en stat har vanskeligheder knyttet til refinansiering af lån eller ny lånoptagelse. Men man kan yderligere tale om en særlig statsgaldsfalde. ${ }^{8}$ Hermed menes den 'fælde', der opstår, når en stat med en i forvejen stor statsgæld og en usikker økonomi bliver udsat for at måtte betale højere renter end tidligere (og end andre stater) ved refinansiering af sin gæld. Renterne har for Grækenland været helt oppe 
over $20 \%$, men selv renter på over $6-7 \%$, som flere stater har oplevet, anses for problematiske. Konsekvensen er, at særligt belastede stater bliver yderligere belastede, altså en meget truende og hurtigtvirkende negativ spiral.

Problemerne knyttet til statsgældskriser og statsgældsfælden kan siges at være generelle og også kendte, bl.a. fra udviklingslande. Man har imidlertid mødt en serlig forsterket variant af statsgaldsfelden for stater i eurozonen. Det forhold, at en stat er medlem af eurozonen og altså har euroen som valuta, indebærer, at en række instrumenter for økonomisk politik (således devaluering, selvstændig rentepolitik og finansiering igennem seddelpressen) ikke står til rådighed for den pågældende stat. Det betyder, at staten grundlæggende skal finansiere og genfinansiere sin gæld igennem udstedelse af statsobligationer. Spørgsmålet om tillid eller ikke tillid til staten er således ikke blevet fjernet, men giver sig nu - måske endnu mere - udslag i renten ved refinansiering. Desuden kan der være en afsmittende virkning på andre stater inden for samme valutaområde.

\section{Det sarlige graske problem}

I forløbet af kriserne omkring euroen er det efterhånden (men temmelig sent) blevet klart, at Grækenland udgør et helt særligt tilfælde. Problemerne i Grækenland er ikke kun, at staten har oparbejdet en stor gæld, som man ikke selv kan finansiere, men også en række andre problematiske samfundsforhold. Mange af disse problemer har en historisk fundering. Ét har været, at Grækenland kom ind i eurosamarbejdet efter en sådan forskønnelse af regnskabstal, at det må anses for at være kreativ bogføring. Naturligvis gælder det at EU-landene i sin tid enten var eller burde have været bekendt med dette. Et andet problem er, at de tidligere græske regeringer har været meget letsindige med optagelse af store lån. Det mest centrale, som gør Grækenlands situation speciel, er imidlertid, at krisen i Grækenland har afsløret, at der er store problemer knyttet til den offentlige sektors funktionsdygtighed i Grækenland, bl.a. et helt utilstrækkeligt skatteopkrævningssystem og udbredt korruption og nepotisme. I reaktionerne på Grækenlands anmodning om lånebistand er landet blevet behandlet på en særlig måde. Grækenland er således også unikt i den forstand, at det er det eneste af de kriseramte lande, som i forbindelse med forhandlingerne om nye lånepakker har opnået en reel, delvis gældseftergivelse (en såkaldt „haircut“). Uanset enigheden i slutningen af $2012 \mathrm{om}$ at lade endnu en lånepakke til Grækenland komme til udbetaling, er landets problemer fortsat af en sådan størrelsesorden, at hverken en hel eller delvis statsbankerot eller en udtræden af euroen er udelukket.

'Det græske problem' kan siges at være unikt inden for EU i sammenligning med de øvrige staters problemer.
Men det er vigtigt at erkende, at det har en vis generel karakter. Der er grundlæggende tale om et problem knyttet til den græske statsdannelse, idet denne fremstår som det, man i international politik betegner som en 'svag stat', dvs. en stat, som ikke er i stand til at varetage basale statsfunktioner. Det er naturligvis en særlig udfordring, også for eurosamarbejdet, at man i alt for høj grad synes at være gået ud fra, at man har at gøre med etablerede og velfungerende stater, der kan styres ved retlige-administrative politikker, mens dette ikke bare kan forudsættes.

\section{EU's reaktioner på de økonomiske kriser}

Hvis vi vender os til spørgsmålet, hvorledes EU har forholdt sig til de forskellige kriser, der er skitseret i det foregående afsnit, er det grove svar, at EU i virkeligheden både har været ganske langsom og ganske selektiv i sine reaktioner (Østrup, 2012). Man kan sige, at EU primært har forholdt sig til budget-og statsgaldskriserne. Det dominerende billede har meget længe været, at der har været tale om en 'Schuldenkrise', et 'sovereign debt problem', der er fremstået, fordi de pågældende stater ikke har formået at levet op til ØMU'ens krav.

Da først Grækenland og derefter Irland, Portugal og Spanien meldte sig med problemer, der indebar voldsom overskridelse af budget- og statsgældsreglerne, men desuden havde elementer af, at de pågældende lande var ved at komme i egentlige statsgældsfælder, blev det klart, at man var ude over den normalitet, man havde forudsat ved konstruktionen af ØMU'en. Hovedbestræbelsen i Stabilitets- og Vækstpagten havde været at skabe regler der slog fast, at hvert land skulle holde styr på egne finanser. Det var endda regler, som man havde taget forholdsvis let på. ${ }^{9} \mathrm{Nu}$ måtte man nu forholde sig til den situation, at det ikke kunne lade sig gøre at løse problemerne alene ved regelopstramning. Det var klart, at ØMU'en slet ikke var forberedt på at skulle etablere garantier eller lån til nødstedte lande. ${ }^{10}$

En meget stor del af EU's - forhandlingsmæssigt noget omstændelige - reaktion på kriserne har været, 1) at man i flere omgange har strammet det kontrolregime, der tidligt blev formuleret med konvergenskriterierne og i Stabilitets- og Vækstpagten, og 2) at man har suppleret dette regime med garanti- og lånemuligheder for stater med akutte gældsproblemer. Hertil kommer, 3) at man i efteråret 2012 har taget skridt til etablering af en bankunion og 4) igangsat en proces til 'fuldførelsen af ØMU'en'.

Det fører for vidt her at gennemgå de mange tiltag fra EU's side, der ligger i forlængelse af den tidlige Stabilitetsog Vækstpagt. ${ }^{11}$ Hovedpointen her er ikke en konkret gennemgang af disse mange skridt, men den tolkning, at de nyere tiltag i høj grad må forstås som en fortsættelse af 
den tidlige retlige-administrative kontrolstrategi. ${ }^{12}$ Tiltagene omfatter ud over de tidlige stramninger af regler og procedurer og en udbygning i efteråret 2011, bl.a. med de særlige forordninger der kaldes 'Six Pack', som også indpasser overvågningen af medlemslandenes makroøkonomiske forhold i det såkaldte Europæiske Semester. Også den såkaldte Finanspagt fra 2012 kan ses som en fortsættelse af denne strategi. ${ }^{13}$ Hovedprincippet er fortsat, at hver stat er ansvarlig for sin egen makroøkonomi, men at der samtidig er en retlig-administrativ kontrol fra EU, som sikrer, at der ikke opbygges store underskud og stor gæld. En af de centrale stramninger i Finanspagten er, at deltagerlandene forpligter sig til at holde deres 'strukturelle budgetunderskud' under 0,5\% af BNP. Den retlige karakter af forpligtelserne understreges ved, at det er EU-Domstolen, der ifølge Finanspagten er den sanktionerende myndighed. ${ }^{14}$

EU's anden hovedreaktion har som nævnt været at etablere garanti- og lånemuligheder for særligt truede stater. Man oprettede i begyndelsen af 2010 den midlertidige europæiske finansielle stabilitetsfacilitet (EFSF), og denne blev i september 2012 udvidet til den permanente stabilitetsmekanisme (ESM). Denne nye fælles institution har en samlet effektiv udlånskapacitet på 500 mia. euro. Finansiel støtte fra mekanismen kræver en anmodning fra et medlemsland fra euroområdet, samt at støtten vurderes nødvendig af hensyn til euroområdets stabilitet. Vurderingen vil ske på baggrund af en bæredygtighedsanalyse af statsgælden, som foretages af Kommissionen og IMF i samarbejde med ECB. Finansiel bistand fra mekanismen vil blive underlagt strenge krav til det pågældende euroland om et makroøkonomisk tilpasningsprogram.

Uanset ovennævnte tiltag har EU ikke kunnet komme uden om problemet vedrørende statsgeldsfalder. Lånetilsagnene, etableringen af udlånsmekanismerne og mange erklæringer beroligede ikke markederne for de mest udsatte stater. Nogle af disse har måttet betale høje renter i forbindelse med deres gældskonverteringer. Det er blevet klart, at markederne også inden for eurosamarbejdet kan spekulere imod enkelte stater, eventuelt også spekulere i egentlige statsbankerotter eller i politiske redninger af stater. Interessant nok har den erklæring, som chefen for den Europæiske Centralbank, Mario Draghi, afgav i september 2012 om, at ECB ville være villig til at opkøbe obligationer fra de særligt ramte stater „i ubegrænset omfang", haft den virkning, at toppen er taget af renterne for disse landes obligationer. Truslen om egentlige statsgældsfælder synes at være blevet mindre, men den er ikke forsvundet, og ECB's opkøb er endnu ikke sat på nogen afgørende prøve. Man skal lægge mærke til, at opkøbene fra ECB vil være betingede af, at de pågældende lande gennemfører reformprogrammer i overensstemmelse med bl.a. IMF's anbefalinger.

I forhold til den finansielle krise i 2008 var reaktioner i Europa i første omgang nationale, og EU var længe temmelig passiv over for den finansielle sektor vanskeligheder (Østrup 2012). Man enedes dog i oktober 2008 om en række koordinerende retningslinier for stabilisering af finanssektoren, herunder regler om, at nationale tiltag ikke måtte ske på bekostning af andre EU-stater. Desuden øgede man - under hensyn til at særligt bankpakkerne vejede tungt på statsbudgetterne - mulighederne for undtagelser fra kravene i Stabilitets- og Vækstpagten. Dette er senere fulgt op med en række mere konkrete bestemmelser angående bankernes virksomhed, et fælles europæisk konjunkturprogram og en forøgelse af Den Europæiske Investeringsbanks aktiviteter. Den Europæiske Centralbank engagerede sig desuden kraftigt i likviditetsstyring og førte en lavrentepolitik for at lette forholdene på finansmarkederne. I 2009 blev EU's løbende informationsoversigt over de finansielle markeder styrket. I 2010 etablerede man en 'European Banking Authority' som bl.a. gennemførte 'stress-tests' for de europæiske banker. Der har været et forslag til mere vidtgående tiltag, bl.a. om beskatning af finansielle transaktioner (indførelse af en såkaldt 'Tobin-skat'). Man kunne dog i sommeren 2012 ikke enes om et sådant forslag, men der er udsigt til at Frankrig, Tyskland og 8 andre EU-lande (hvor Danmark ikke er med) vil iværksætte et såkaldt 'forstærket samarbejde' herom. Yderligere blev der i september 2012 fremsat forslag om etablering af en egentlig bankunion, og tankerne herom blev yderligere konkretiseret ved mødet i DER i december 2012. Det er fortsat uafklaret, i hvilken udstrækning og på hvilken måde ECB’s tilsyn med bankerne skal inddrage andre EU-lande end eurolandene.

I forhold til den generelle økonomiske krise og dennes forskellige elementer har EU's indsats været begrænset. Man har fastholdt Europa 2020-strategien, men det er åbenbart, at en del af dennes formuleringer er blevet undermineret af den aktuelle krise. F.eks. læser man næppe $ø$ nsket om „inklusiv vækst: fremme af en økonomi med høj beskæftigelse, der sikrer social og geografisk samhørighed" på samme måde som tidligere (jf. Kelstrup et al., 2012, s. 203). EU vedtog i juni 2012 en vækstpakke på angiveligt 120 mia. euro, bl.a. på foranledning af den franske præsident Francois Hollande. Der var i høj grad tale om en art genbrug af allerede bevilgede penge. En stor del af beløbet (55 mia. euro) opnås ved, at EU's strukturfonde gøres nemmere tilgængelige, mens en anden del (der er uspecificeret) opnås ved en vedtagelse om, at EU's eget budget også skal kunne bruges til at stimulere nye jobs. Yderligere 10 mia. gives som kapital fra medlemslan- 
dene som tilførsel til Den Europæiske Investeringsbank, mens 4,5 mia. skal nås ved udstedelse af projektobligationer.

Naturligvis er det et vigtigt spørgsmål, hvorfor EU har gjort så relativt lidt i forhold til den faktisk økonomiske udvikling i Europa, f.eks. i forhold til bekæmpelse af arbejdsløshed og i forhold til de lande der særligt er ramt af den økonomiske krise. Et forhold er, at denne type opgaver traditionelt og primært henhører under hver enkelt stats anliggende. Men årsagerne er også knyttet til EU's og ØMU'ens konstruktion. EU's institutioner har med de nuværende regler for ECB og EU's budget kun i meget begrænset omfang mulighed for at føre egentlig konjunkturpolitik, og f.eks. Kommissionen kan grundlæggende kun anvende penge, der er bevilget af staterne. Der er således skrappe strukturelle begrænsninger for, hvad Kommissionen kan gøre. Situationen er i den aktuelle fase tilspidset af, at også staterne begrænses i at føre konjunkturpolitik. I opstramningen af reglerne for ØMU'en har man i endnu højere grad end tidligere lavet stramme regler for balance i de statslige budgetter. Konsekvenserne er, at de enkelte stater må føre en 'besparelsespolitik', som implicerer, at de offentlige finanser virker kontraktivt i forhold til den i forvejen indskrænkede økonomiske aktivitet. Denne besparelsespolitik, der muligvis slet ikke er gennemtænkt som økonomisk politik, men netop mere som kontrolpolitik, virker direkte imod en EU-beskæftigelsespolitik. EU synes således at have prioriteret et kontrolpolitisk forsøg på at løse statsgældskriserne over tiltag til fremme af økonomisk aktivitet og beskæftigelse.

Der kan også peges på ideologiske og politiske forhold, der begrunder at EU ikke har lagt mere vægt på de økonomiske kriser i de mest ramte lande (PIIGS-landene). Grundlæggende strider det imod EU's ideologi om det indre marked, at der har udviklet sig en stor ulighed inden for EU. Grundtanken både for det indre marked og ØMU'en har været, at forskelle i løn og beskæftigelse vil kunne udlignes igennem mobilitet. Der synes at være en uvilje imod at erkende, hvor ulige en udvikling der har fundet sted inden for eurozonen. Det grundlæggende ræsonnement synes fortsat at være, at de pågældende stater med en fornuftig politik bør kunne gøre sig lige så konkurrencedygtige som andre dele af EU. Man er ikke så optaget af, hvordan dette kan ske (da det er et nationalt ansvar), eller af hvor usandsynligt det forekommer, at dette sker, både i det hele taget og i lyset af den besparelsespolitik, der føres. Man kan sige, at EU's institutioner er ikke indrettet til at gå ind i spørgsmål knyttet til ulige udviklinger - ud over struktur- og regionalfondene. Der er også en egentlig politisk dimension på spil. Den dominerende politik har traditionelt - og særligt i Tyskland - været temmelig neoliberal, og den nuværende konser- vative-liberale regering har ikke ønsket at styrke EU som en fordelingspolitisk union ('Transferunion'), uanset at forbundskansler Angela Merkel dog har været aftvunget visse indrømmelser i den retning. ${ }^{15}$ Måske bør man føje til, at den tyske offentlighed i vid udstrækning er blevet domineret af et forsimplet billede af, at grækerne har levet over evne, mens tyskerne betaler, mens der er blevet lagt mindre vægt på det tidligere så vigtige billede af, at tyskerne frem for alt - og i egen interesse - måtte støtte en samlet og solidarisk europæisk udvikling. ${ }^{16}$

EU har viet det greske problem stor opmærksomhed, bl.a. fordi det var problemerne i Grækenland, der i særlig grad indeholdt truslen om, at et medlem af eurozonen ville gå statsbankerot. EU har bidraget til løsning af den græske stats meget store gældsproblemer både ved ydelsen af lån i flere omgange, ved en nedskrivning ('haircut') af gælden i oktober 2011 og ved en særlig, betinget lånepakke i december 2012. EU har i forbindelse hermed i samarbejde med IMF engageret sig omfattende $i$, hvilke reform- og spareprogrammer man har fundet nødvendige for Grækenland. EU's prioritering synes også her at være en løsning på den græske stats gældsproblemer. Det forekommer fortsat problematisk og meget underbelyst, hvorledes Grækenland - med sin arbejdsløshed, sin vidtgående sparepolitik og sine vanskeligheder med at få statsapparatet til at fungere - inden for en overskuelig tid skal komme frem til at kunne klare sig.

Samlet set viser en opdeling af eurokrisen i forskellige kriser (hvor uklar selve opdelingen end kan være) at EU's reaktioner på kriserne har givet en meget høj prioritet til budget- og statsgældsproblemerne og til en administrativ-retlig kontrolstrategi, der ligger i forlængelse af ØMU'ens konvergenskrav og de strammede regler fra Stabilitets- og Vækstpagten. Omtalen af de andre kriser, der er involveret i eurokrisen, viser at der er en række meget alvorlige problemer, som EU tilsyneladende ikke har troværdige løsninger på. Der er tilløb til en øget kontrol med finanssektoren, bl.a. i forslaget om en bankunion med fælles banktilsyn, men forhandlingerne herom er fortsat uafsluttede. Der er en vækstpagt, men den er af begrænset omfang, og der er strukturelle bindinger der gør den begrænset. I forhold til de økonomiske problemer i de særligt ramte lande synes problemet at være, at den strategi eller 'medicin', man foreskriver - drastisk besparelsespolitik - nærmest synes at gøre patienterne mere syge. Det opretholdes som den dominerende tolkning, at alle nuværende eurolande skal forblive i euroen. Det er dog et fundamentalt problem, at man ikke på nogen troværdig måde kan forklare, hvorledes Grækenland inden for en overskuelig tid vil kunne få så sund en økonomi, at man vil kunne klare sig fremover, og problemet stiller sig i nogen udstrækning på samme måde for de andre, hårdt 
ramte lande. Den simple analyse, der er foretaget ovenfor, viser, at der er meget forskellige økonomiske udviklinger i det europæiske rum. I EU's reaktioner på krisen synes man at mangle svar på, hvorledes de problemer, der følger af de ulige udviklinger, skal løses - og løses i en situation, hvor det ikke længere er muligt for noget euroland at genoprette sin konkurrenceevne ved en devaluering.

\section{Perspektiver}

\section{Fra økonomiske til politiske kriser}

Det er ikke vanskeligt at konstatere, at der er fulgt alvorlige politiske problemer i kølvandet på eurokrisen. Uden at gå ind i en egentlig analyse, kan man slå fast, at der i hvert fald er tale om følgende alvorlige udviklinger:

1) Der er en kraftig splittelse mellem Storbritannien og det øvrige EU. Denne modsætning er kendt fra tidligere, men synes at være vokset med eurokrisen. Splittelsen viste sig tydeligt på topmødet i Det Europæiske Råd i december 2011, hvor Storbritannien ikke kunne gå med til den politik, der efterfølgende blev til Finanspagten (hvilket forklarer at denne blev mellemstatslig). Modsætningen fortsatte i efteråret 2012 i EU's budgetforhandlinger samt Storbritanniens afstandtagen til forslaget om en bankunion. Både holdningerne i den britiske befolkning og de engelske politikeres formulering peger på en forøget euroskepsis i Storbritannien. En undersøgelse fra november 2012 viste at $56 \%$ af befolkningen ønsker Storbritannien ud af EU (The Observer, 18.11.2012). Det forekommer mere og mere sandsynligt, at Storbritannien er på vej ud af EU.

2) Der er tendenser til en splittelse mellem eurolandene og de øvrige EU-lande. Selve etableringen af eurosamarbejdet førte til en særlig formalisering af dette i eurogruppen, som gradvis er blevet mere betydningsfuld. Eurokrisen ser ud til at forøge skellets betydning. Etablering af en bankunion mellem eurolandene vil formentlig skabe problemer i forhold til de lande, der ikke er med, og måske også i forhold til hele det indre marked (Wind, 2012). Hvis styrkelsen af det institutionelle samarbejde mellem eurolandene fører til en egentlig føderalisering, vil EU fremover i endnu højere grad end nu have Amedlemmer og B-medlemmer. Hvis Europa-Parlamentet skal deles, således at der gælder særlige regler for parlamentarikere fra eurolandene, vil dette næppe fremme det samlede parlaments arbejde. ${ }^{17}$

3) Måske er der også stigende modsætninger mellem de sydeuropæiske og nordeuropæiske lande. Måske skal man snarere formulere dette som modsætninger mellem de lande, der har overskud på betalingsbalancen, og de der ikke har det. En vanskelighed er, at de forholdsvis få EU-stater, der har overskud på betalingsbalancen og dermed grundlæggende har de bedste muligheder for at bidrage til løsning af EU's arbejdsløshedsproblemer, samtidig er underlagt det tidligere omtalte pres fra den internationale konkurrence.

4) Der er voksende økonomiske, sociale og politiske uro i de mest ramte områder, og der er flere tilfælde af sociale og politiske protestaktioner. Det er muligt, at dette vil udvikle sig til endnu større politiske kriser. Utilfredshederne synes både at rette sig imod EU og mod nationale myndigheder. I nogle tilfælde spiller denne forøgede euroskepsis sammen med højrenationale protestbevægelser (som f.eks. i Ungarn, Polen, Finland og Grækenland).

I en refleksion over udviklingen kan man sige, at det ikke var givet på forhånd, at reaktionen i EU på de vanskeligheder, der er kommet med eurokrisen, skulle føre til så store splittelser. Man må undre sig over, at den type 'forhandlingsfælleskab', der havde ført frem til Lissabontraktaten og et relativt velfungerende eurosamarbejde i 2009, ikke har give bedre svar på eurokrisen. Set i dette perspektiv har håndteringen af eurokrisen også karakter af en ledelseskrise. Et markant forhold er, at der ikke har været noget godt samspil mellem EU's institutioner og de mest centrale statslige ledere. Således har både Kommissionen og Europa-Parlamentet befundet sig på et sidespor i forhold til kriseløsningerne. Et andet problemer er, at de centralt placerede statsledere, særligt den tyske kansler, Angela Merkel, og den franske præsident (først Sarkozy og derefter Hollande) nok har kunnet etablere en vis form for ledelse, også i situationer hvor dette har været vanskeligt, men det er ikke lykkedes - og der har måske heller ikke været vilje til - at lægge en fælles, europæisk linje som har kunnet fremstå som hævet over de pågældendes mere specifikke interesser. Måske skal man også tale om et 'forståelses- eller paradigmeproblem" og en 'intellektuel stiafhængighed' af konventionelle forestillinger. En del af den manglende ledelse er måske udtryk for en utilstrækkelig forståelse af basale økonomiske forhold. ${ }^{18}$

\section{Forslag om nye strukturer og traktatendringer}

I forsøgene på at komme videre arbejder Det Europæisk Råd under ledelse af formanden, Herman van Rompuy, med en plan for, hvorledes EU - og i særdeleshed Eurolandene - mere grundlæggende skal reagere på Eurokrisen. På mødet i Det Europæiske Råd i juni 2012 vedtog statsog regeringscheferne bl.a. at give van Rompuy opgaven at skitsere en grundlæggende ændringer af Eurosamarbejdet. ${ }^{19}$ Rompuy fremsendte i oktober 2012 en foreløbig rapport herom med titlen: „Hen imod en egentlig økonomisk og moneter union". Hovedlinjen er, at der lægges op til en vidtgående bankunion mellem eurolandene, en egentlig finanspolitisk union mellem disse, en styrkelse af EU's mekanismer til overvågning og koordinering af de pågældende landes økonomiske politik, og institutionelle 
ændringer, der sikrer inddragelse af demokratiske organer, særligt Europa-Parlamentet. ${ }^{20}$ Tankerne går i retning af en 'føderalisering' med en styrket, overnational myndighed for eurozonen på det økonomiske område.

Det fører for vidt her at gå konkret ind på Herman van Rompuys tanker, og retfærdigvis må den egentlige diskussion komme senere, når forslagene på området er konkretiseret. Det Europæiske Råd drøftede planen på sit møde i december 2012 og gav tilslutning til en køreplan for de fremtidige drøftelser af denne. EU står således nu over for en forhandlingsproces, der lægger op til grundlæggende ændringer af EU, særligt af eurozonen, og traktatændringer i overensstemmelse hermed.

Naturligvis rejser der sig en række meget væsentlige spørgsmål, såfremt EU udvikler sig på en sådan måde i to hastigheder med en særlig - tilsyneladende føderal struktur for eurozonen. Noget sådant aktualiserer diskussionerne om Europa i flere hastigheder. ${ }^{21}$ De fremførte tanker går i retning af at øge det allerede eksisterende skel i EU mellem medlemmer af eurozonen og lande der ikke er medlem af denne. Tankerne synes også at gå i retning af en yderligere formalisering af den retlige-administrative kontrolpolitik, som har været dominerende i EU's hidtidige reaktioner på eurokrisen, hvilket bestyrker det perspektiv der er anlagt ovenfor. Den grundlæggende forstålse ser ud til stadig at lægge hovedvægten på øget konkurrenceevne og at forudsætte, at der skal og vil ske konvergens imellem eurolandene. Det er spørgsmål knyttet til kontrol med stater og banker, der dominerer.

\section{Nogle forsøgsvise vurderinger}

Lad os afslutningsvis søge at give nogle mere sammenfattede svar på de spørgsmål, der blev stillet i indledningen til artiklen: Hvorfor gik det galt? $\mathrm{Og}$ hvad er perspektiverne? Dette er naturligvis spørgsmål, der ikke kan gives sikre svar på. Her er kun plads til nogle forsøgsvise sammenfatninger.

Ser vi først på spørgsmålet om, hvad der er gået galt, skal følgende betragtninger fremføres, uden at det her kan diskuteres, hvilke af dem der er mest rigtige:

1) En forklaring på eurokrisen kan (ud over dens basis i finanskrisen) være, at der er en 'konstruktionsfejl' i ØMU'en. Mange har været inde på dette (Jespersen, 2012). Selve det forhold, at Rompuys seneste oplæg handler om, at man skal hen mod en 'egentlig' Økonomisk og Monetær Union, viser også at man i EU's ledelse har accepteret at der er mangler i den hidtidige ØMU. Lidt konventionelt kan man hævde, at fejlene er, at man ikke har forudset, at der kan komme så alvorlige 'udefra kommende stød', som tilfældet har været, at man har været for naive i troen på, at statsledere har villet holde deres formelle forpligtelser, eller at man ikke har forudset at gældskriserne har kunnet få et så stort omfang, at man derfor heller ikke har forudset, behovet for en omfattende mekanisme til at sikre lånemuligheder og programmer for at genetablere basale ligevægte, og at man grundlæggende har haft for stor tillid til bankerne. Det synes i høj grad at være disse mangler, man er ved at råde bod på.

2) En mere vidtgående tolkning er, at tankerne bag ØMU'en og dens udligningsmekanismer ikke tilstrækkeligt tager højde for, at der - af en lang række årsager - kommer meget forskellige udviklinger i euromedlemmernes økonomi, herunder også deres produktivitet. ${ }^{22}$ Over for disse problemer kan man mangle den udligningsmekanisme, der ligger i en devaluering. Fejlen er, kan man efter denne tolkning sige, at man af forskellige grunde har 'overset', at den faktiske eurozone ikke er noget optimalt valutaområde, og at dette kan få meget alvorlige konsekvenser.

3) En tredje art forklaring kan imidlertid være, at den fejl, vi har at gøre med, drejer sig om en 'bureaukratisering' af økonomisk politik som følger af internationale forhandlinger. Fejlen er i dette perspektiv, at ØMU'en lægger op til en problematisk økonomisk politik, fordi karakteren af de internationale forhandlinger (og den eksisterende mistro mellem stater) fører til en stor optagethed af retlig og administrativ kontrol. Dette fører let til den forståelse, at ansvarlig økonomisk politik indebærer 'besparelsespolitik'. Der er noget, der tyder på, at ØMU'en ikke har været ledsaget af egentlig makroøkonomisk tænkning. Problemet med ØMU'en har ud fra dette perspektiv været, at man har etableret en art styringsmekanisme, der ikke er konjunkturfølsom. EU/ECB har ikke fået noget middel til at føre en finanspolitik på samme måde som stater (der ikke er medlemmer af EU) har det. Problemet viser sig i krisetider ved, at den politik, der går ud på at sikre staternes balancer igennem besparelser på de offentlige budgetter, den såkaldte 'austerity policy', er problematisk i en situation med arbejdsløshed og manglende vækst, fordi den har kraftige kontraktive og selvforstærkende elementer.

4) En fjerde tolkning er også mulig, nemlig at der slet ikke er tale om en egentlig 'fejl' i udformningen af ØMU'en, men om et politisk projekt, der først nu viser sig i sine konsekvenser. Der var allerede ved ØMU'ens vedtagelse kritik af, at denne - ved sin prioritering af inflationsbekæmpelse - også lavede en vidtgående fastlåsning af staterne til en monetaristisk stabilitetspolitik og ikke til en keynesiansk konjunkturpolitik. Når ØMU'en alligevel blev vedtaget, som den gjorde, kan det ses som et resultat af den politiske kamp, der var om udformningen af det økonomiske projekt.

Naturligvis forekommer det også særdeles vanskeligt at svare på det andet spørgsmål, der blev formuleret i 
indledningen til denne artikel: Hvad er perspektiverne for ØMU-samarbejdet? Det billede, der er tegnet ovenfor, er, at perspektiverne er meget negative. Eurokrisen har mange delproblemer, og på en række områder er de faktiske forhold meget problematiske. I særdeleshed er den ulige udvikling og situationen omkring arbejdsløshed og sociale forhold i de særligt ramte lande ganske alarmerende. Det gælder endnu mere, hvis man inddrager de politiske problemer, som følger i kølvandet på de $ø$ konomiske.

Et vigtigt perspektiv er de tanker, der ovenfor er omtalt i forbindelse med Herman van Rompuys seneste rapport, og som nu vil blive konkretiseret og genstand for forhandlinger mellem EU-staterne. Perspektivet her er især, at det kan indebære en egentlig 'føderalisering' af eurozonen, forstået som en etablering af en egentlig finansiel union for disse stater med overnational myndighed i finansielle spørgsmål. I én tolkning vil dette indebære, at EU og ØMU-en hermed får en meget stærkere og mere effektiv formel struktur i form af en egentlig finansunion. Det ideelle billede vil utvivlsomt for de fleste være, at dette kan ske i fuld harmoni med de lande, der ikke deltager i euroen. Vi vil da - ifølge den optimistiske tolkning - stå med et 'kerneeuropa', hvor denne kerne er den 'gode leder' for hele Europa. En ganske anden udlægning er dog, at et forsøg på at etablere en sådan struktur vil løbe ind i meget store problemer. Forslaget om et Europa i to hastigheder kan, som det allerede er antydet ovenfor, meget let medføre en lang og problematisk forhandlingsproces, nye splittelser, en stor optagethed af formelle kompetencer og en gentagelse af meget af den institutionelle selvoptagethed, som mange husker så udmærket fra EU's forfatningsdebat. Det virkeligt problematiske $\mathrm{i}$ en forhandlingsperiode af denne karakter er, at dette meget vel kan føre opmærksomheden væk fra andre centrale problemer. Blandt andet fra det helt centrale problem: hvilken økonomisk politik kan man føre i et arbejdsløshedsramt Europa med store økonomiske problemer og meget stor ulighed? Det vil fortsat være utroværdigt, at en retlig-administrativ politik, der nu - hvis processen lykkes - hæves op på traktatniveau, vil være et svar på dette spørgsmål.

Farerne ved de nye tanker om et Europa i to hastigheder er - efter mit skøn - ikke kun de problemer, som selve denne proces giver anledning til, eller de problemer, som måtte opstå, såfremt vi virkelig får et sådant „kerneeuropa“. Faren er også alle de problemer, der ikke kommer på dagsordenen, hvis spørgsmål om traktatændringer endnu engang skal 'erobre' de politiske debatter. I stedet for at sætte traktatændringer og ny føderalisering af eurozonen på dagsordenen, er det vigtigt at få mere åbenhed ind i debatterne om, hvad man kan og bør gøre.
Er det f.eks. ikke relevant at drøfte, om det kan lade sig gøre at lave ordninger, hvor enkelte lande får mulighed for at trække sig ud af eurozonen, eventuelt for at gå over i et system, hvor de har fast, men justerbare vekselkurser? Er det ikke muligt mere effektivt at lave programmer, der yder bistand til de befolkningsgrupper, der er særlig ramt af den aktuelle krise? Er debatten om skabelse af 'eurobonds' udtømt? Skal man virkelig gøre 'konkurrenceevne og konvergens' til de centrale målsætninger, når situationen er, at man ikke får konvergens i praksis? Er det så sikkert, at man skal acceptere det tyske standpunkt, at EU ikke skal være en 'transferunion' (altså bidrage til ressourceoverførsler), når nu fordelene ved at deltage i unionen er ulige fordelt, og når man nu i øvrigt er meget ivrige for at bruge ordet solidaritet? Skal det afvises, at det kan være en meget fornuftig politik faktisk at få i hvert fald en vis inflation, således at både de store finanskapitaler og de store gældsbyrder herved kan formindskes? Skal man ikke tænke mere grundlæggende igennem, hvorledes den bestandige fokusering på vækst kan modificeres og tilpasses de på langt sigt uafviselige krav om bæredygtighed? De mulige spørgsmål er mange. Rigtig mange af de relevante politikker vil man udmærket - hvis der i øvrigt opnås politisk enighed og vilje - kunne gennemføre inden for EU's nuværende strukturer. Det vil være meget synd, hvis en ny debat om en føderalisering af eurozonen, der oven i købet truer med at fastlåse en problematisk retlig-administrativ tilgang til økonomiske problemer, skal komme til at dominere diskussionen om, hvad der kan gøres.

\section{Konklusioner}

Denne artikel har forsøgt at vise, at Eurokrisen drejer sig om mange forskelligartede kriser. Basale forhold angående nogle af disse er skitseret. Artiklen har forsøgt særligt at differentiere billedet af de økonomiske kriser. Det er vist, at EU har ageret både langsomt og meget selektivt i forhold til de forskellige kriser. Man har grundlæggende fulgt en linie, der 1) strammer ØMU'ens og Stabilitetsog Vækstpagtens tidligt formulerede konvergenskrav og supplerer disse med procedurer for budgetkontrol, 2) supplerer dem med en (i flere faser udbygget) lånemekanisme, der også kobles med vidtgående reformkrav, og 3) taget indledende skridt dels til en skærpet kontrol med bankerne i eurozonen. Den dominerende politik er en retligbureaukratisk kontrolpolitik, der i praksis bliver til en $ø$ konomisk besparelsespolitik. Der er argumenteret for, at der er meget alvorlige sider af den økonomiske krise, som denne politik ikke har nogen løsning på. I den sidste del af artiklen er der peget på, at den førte politik er medvirkende til store politiske kriser. Desuden er det hævdet, at en politik, der fører i retning af et opdelt EU med en 
særlig formel struktur for eurolandene, kan have meget negative virkninger, uden at den indeholder politiske løsninger på de elementer af eurokrisen, der ikke direkte er knyttet til budgetkontrol. Der er peget på, at en ny traktatdebat alt for let kan komme til at aflede opmærksomheden fra centrale problemer, som Europas ledere bør forholde sig til. Der kan meget vel komme yderligere skærpelse af politiske kriser i dele af EU, som på anden måde vil sætte spørgsmål knyttet til den ulige udvikling i Europa på EU's dagsorden. Den samlede konklusion er, at EU ser ud til at være på en meget problematisk kurs, både i relation til de faktiske kriser i Europa $\circ g$ med de aktuelle tanker om etablering af en særlig føderativ struktur for Eurozonen. Det er formentligt helt rigtigt, at kriser i høj grad kan bidrage til ny udvikling af EU. Men netop derfor er det også vigtigt, at det er de rigtige spørgsmål der stilles i forlængelse af en krise. Selv om der i øjeblikket synes at være grund til at være pessimist angående EU's fremtid, skal denne pessimisme dog ikke overdrives. EU har tidligere vist læreevne, og det er heldigvis muligt at fremtidige valg og de kommende forhandlinger vil ændre de aktuelle perspektiver.

\section{Noter}

1. Se Kelstrup et al., 2012, for en udbygget beskrivelse af den forståelse af EU som et politisk og retligt system, der her lægges til grund.

2. Kilder til tallene i dette afsnit: Eurostat, jf. også Arbejderbevægelsens Erhvervsråd, 2013.

3. Fremstillingen i dette afsnit baserer sig i vid udstrækning på Kelstrup et. al., 2012, s. 303-323.

4. Et særdeles vigtigt spørgsmål er, på hvilken måde (og i hvilken grad) presset fra den øgede globalisering påvirker staternes handlemuligheder. Der er næppe tvivl om, at der diskursivt konstrueres imperativer fra globaliseringen, jf. bl.a. Colin Hay og Ben Rosamonds analyse (Hay \& Rosamond, 2002). Sådanne konstruktioner genfindes i påstande om, at staterne nu er blevet - eller bør blive - 'konkurrencestater', jf. Pedersen, 2011. En uddybning udelades her, men er naturligvis vigtig for forståelse af rammebetingelserne for eurokrisen.

5. Måske er det rigtigste at se globaliseringen som en mulighed for nogle (konkurrencedygtige) stater, men som problemskabende for andre stater. I opregningen af rammebetingelserne for EU's økonomi bør man imidlertid også medtage, at EU's økonomi befinder sig i en fase, hvor en omstilling til en bæredygtig økonomi både er påtrængende og på længere sigt uafvendelig, jf. bl.a. Nielsen, 2012, Hedegaard, 2012. Dette forhold er dog holdt uden for analyse for ikke at overbelaste denne.

6. Den forskellige udvikling $\mathrm{i}$, unit labour cost" ses af nogle analytikere som en hovedforklaring på den ulige udvikling i Eurozonen og dennes vanskeligheder, undertiden forbundet med ønsker om, at Tyskland tilpasser sig på denne dimension (jf. f.eks. Flassbeck and Spieker, 2011).

7. En mere dybtgående analyse må også inddrage såvel udviklingen i private formuer og gæld som sammenhængen med betalingsbalancerne (Jespersen, 2012).
8. Man kan spørge, om det er nødvendigt at sondre mellem statsgældskriser og en særlig statsgældsfælde, idet den sidste kan ses som en tilspidset form for statsgældskrise. Sagen er dog, at dynamikkerne omkring en tilspidset statsgældskrise kan være så stærke og så selvforstærkende, at der kan være en særlig negativ spiral, der truer. Sondringen mellem de to former gør det lettere at stille det interessante spørgsmål: Hvad er afgørende for, at statsgældskriser - måske særligt for små stater i euroområdet - udvikler sig til egentlige statsgældsfælder?

9. Det er kendt, at når man i ØMU'ens historiske udvikling var forsømmelig med hensyn til sikringen af reglernes overholdelse, var en af grundene, at Tyskland og Frankrig var blandt de første stater, der brød reglerne (Kelstrup et al., 302).

10. Der blev ligefrem i sin tid i Maastrichttraktaten indføjet en bestemmelse om, at EU ikke måtte hæfte for medlemsstaternes gæld (tidligere EF-traktaten, artikel 104b, nu TEUF artikel 125). En reaktion i EU var i 2010 at man - særligt på tysk foranledning - fik vedtaget en ændring i traktaten, der muliggør dette. Ændringen er en tilføjelse i TEUF artikel 136 med følgende ordlyd: „De medlemsstater, der har euroen som valuta, kan etablere en stabilitetsmekanisme, der skal aktiveres, hvis det er strengt nødvendigt for at sikre stabiliteten i euroområdet som helhed. Ydelsen af enhver påkrævet finansiel støtte inden for rammerne af mekanismen vil være underlagt streng konditionalitet". Denne traktatændring blev formelt vedtaget på et møde i Det Europæiske Råd den 24.-25. marts 2011. Det forventes, at den træder i kraft i begyndelsen af 2013.

11. For beskrivelser, se Kelstrup et al., 2012, 314 ff., Jespersen, 2012.

12. En beskrivelse ud fra dette perspektiv, også af Finanspagten, findes i Kelstrup et al., 2012, $314 \mathrm{ff}$.

13. Et særligt aspekt ved Finanspagten er, at denne aftale er mellemstatslig. Da EU-landene på topmødet i december 2011 på grund af Storbritanniens modstand ikke kunne enes om en udvidelse af EUtraktaten med pagtens indhold, blev denne gjort til en mellemstatslig aftale indgået mellem alle eurolande samt de øvrige EU-lande, dog undtagen Storbritannien og Tjekkiet.

14. Det kan give anledning til nogen undren, at man forestiller sig at Domstolen på denne måde skal have en afgørende indflydelse på den $ø$ konomiske politiks implementering.

15. Af samme grund er det et vigtigt spørgsmål, hvad der vil ændres, såfremt det skulle lykkes SPD at komme til magten efter forbundsvalget i 2013 .

16. Det er interessant, at begge de tidligere forbundskanslere Helmut Schmidt og Helmut Kohl har kritiseret Angela Merkel for ikke at være tilstrækkelig europæisk i sin tilgang til eurokrisen.

17. For nærmere diskussion af konsekvenserne af Europa i flere hastigheder se bl.a. Kelstrup et al, 2012, 445ff., Piris, 2012, Wind, 2012.

18. Debatten om eurokrisen bliver hermed forbundet med kritikken af den neoliberale, økonomiske tænkning, som må anses som en af årsagerne til den mere generelle finanskrise, jf. tanker fremført af bl.a. Joseph Stiglitz og Paul Krugman (2012), eller konventionelle forestillinger om besparelsespolitik, 'Austerity' (Blyth, 2013).

19. Grundlaget er et papir forfattet af Rompuy med titlen: „En pagt for Euroen. Starkere koordinering af den okonomiske politik med henblik på konkurrencevne og konvergens".

20. Tanker i samme retning findes i en nylig udkommet bog af den tidligere generaldirektør for EU's lovtjeneste Jean-Claude Piris: The Furture of Europe: Towards a two-speed EU?

21. Se også kapitel 14 i Kelstrup et al., 2012 og Wind, 2012.

22. En del af denne tankegang er indeholdt i Jesper Jespersens tanker om, at Eurozonen ikke udgør et 'optimalt valutaområde', Jespersen 2012. 


\section{Referencer}

Arbejderbevægelsens Erhvervsråd, 2013: 26 millioner ledige i EU. Se http://ae.dk/analyse/11-millioner-europaeere-har-vaeret-ledigemere-end-ar

Barsøe, Magnus, 2011: 'Gældskrise. Hvordan kunne det gå så galt?' Politiken, 1.12.2011, s. 10.

Blyth, Mark, 2013: Austerity. The History of a Dangerous Idea, New York: Oxford University Press.

Flassbeck, Heiner and Friederike Spiecker (2011): 'The Euro - a Story of Misunderstanding*. Intereconomics, vol. 46, nr 4, 2011, pp 180-187.

Hay, Colin and Ben Rosamond: 'Globalization, European integration and the discursive construction of economic imperatives', Journal of European Public Policy, Vol. 9, Issue 2, 2002, pp.147-167.

Jensen, Mads Dagnis, 2011: 'Uropa', Reson, nr. 10, 1.12. 2011.

Jespersen, J., 2012: Euroen - hvorfor gik det så galt, og hvordan kommer vi videre? København: Forlaget DEO.

Kelstrup, Morten, Dorte Sindbjerg Martinsen og Marlene Wind, 2012: Europa i forandring En grundbog om EU's politiske og retlige system (2. udgave), København: Reitzel.

Krugman, P., 2012: End This Depression Now, London: Norton and Co. Lynn, M., 2011: Bust: Greece, the Euro, and the Sovereign Debt Crisis. Hoboken, N.J.: Bloomberg Press.

Marcussen, M. \& K. Ronit (red.) 2012: Kriser, politik og forvaltning: De internationale udfordringer. København: Hans Reitzels Forlag.

Nedergaard, Peter, 2008: 'ØMU'en - en solid succes'. Udsyn. Det udenrigspolitiske Selskab.

Nielsen, Jørgen Steen, 2012: Den store omstilling. Fra systemkrise til grøn økonomi. København: Informations forlag.
Piris, Jean-Claude, 2012: The Future of Europe. Towards a Two-Speed EU? Cambridge: Cambridge University Press.

Pedersen, Ove K., 2011: Konkurrencestaten, København: Reitzels Forlag. Talani, L.S. (red.), 2009: The Future of the EMU. New York: Palgrave Macmillan.

Thygesen, N., 2012: 'Euroen, finanspagten og Danmark', Udenrigs, 2012:1, 56-69.

Vastrup, Klaus, 2009: Økonomiske konsekvenser af ØMU'en. DIIS Working Paper 2009:01. Copenhagen: DIIS.

Østrup, Finn, 2012: 'The Future of EU Policy Coordination: Dealing with the Financial Crisis', in Ewa Latoszek, et al., 2012: European Integration Process in the New Regional and Global Settings, Warsaw: WWZ Publisher

Weise, Kristian og Pil Berner Strandgaard, 2012: Europaiske kriseløsninger. København: Cevea

Wind, Marlene, 2012: 'Det nye Europa', i 'Verden i 2013', Reson 02/12: s. $10-14$. 